\title{
United States Policy on China Steel Products Viewed From GATT/WTO
}

\author{
Hilmi Prabowo ${ }^{1 *}$, Nanik Trihastuti ${ }^{1}$, Darminto Hartono ${ }^{1}$ \\ \{hlmprbw@gmail.com ${ }^{* 1}$, naniklaw@live.undip.ac.id ${ }^{2}$, darmintohartono@live.undip.ac.id ${ }^{3}$ \}
}

Fakultas Hukum, Universitas Diponegoro, Jl. Prof. H. Soedarto, S.H., Semarang, Indonesia 50275 ${ }^{1}$

\begin{abstract}
International trade should be conducted without discrimination. The study discusses the adoption of China's steel tariffs by the United States, as well as the efforts to be made by the United States and China to settle steel tariff disputes. This method of research is normative juridical. The results of U.S. studies violated the Most-favourednation (MFN) found in article 1.1 GATT 1947. The settlement of the tariff disputes is conducted through consultation only if it fails to be submitted to DSB. DSB forms a panel to make decisions. Parties who are dissatisfied with the Panel's decisions may forward the matter to Apellatebody, and if this entity fails as well, the dispute resolution then is conducted through the arbitral institutions they choose.
\end{abstract}

Keywords: United States, China, WTO/GATT, dispute rates.

\section{Introduction}

International trade is the commercial activities of the country of origin crossing the border into the destination country carried out by the company to transfer goods, services, capital, labor, technology (factories), and trademarks.[1] International trade has been going on for centuries throughout human history, and has been developing and experiencing dynamically, especially in this era of globalization fading between countries. In modern times, international trade is regulated by the world trade organization or WTO (World Trade Organization) which was formed in 1994. The formation of the WTO is motivated by the need for an organization that can overshadow international trade.[2] Before the WTO, international trade was regulated in the international agreement General Agreement of Tariff and Trade (GATT).

WTO members consist of 164 countries since July 29, 2016.[3] WTO members include the United States and China. The United States has been a member of the WTO since January 1, 1995 while China has been a member of the WTO since December 11, 2001. China has been a member of the WTO for the assistance of the United States during the Bill Clinton administration with the issuance of the US-China Relations Act of 2000 which contained normalizing trade relations with China and providing assistance so that China can become a member of the WTO.[4] As a member of the WTO, China and the United States must trade according to WTO rules and principles, in reality however, there is a trade war between the two countries.

The trade war between the United States and China is in fact due to China's superiority in electronics, shoes, machinery, clothing, and toys. These sectors cause the United States trade to experience a deficit against China. Goods produced by China are superior because they are cheaper. China is the country that causes the most trade deficits in the United States. In 2014 
nearly half $(47.2 \%)$, which amounted to 343 billion of the United States trade deficit caused by China. (United States Trade Representative. press releases: USTR finalizes second tranche of tariff on China's products in response of China's unfair trade .Washington D.C Agustus 2018 Washington, DC - The Office of the United States Trade Representative (USTR) today released a list of approximately $\$ 16$ billion worth of imports from China that will be subject to a 25 percent additional tariff as part of the U.S. response to China's unfair trade practices related to the forced transfer of American technology and intellectual property. This second tranche of additional tariffs under Section 301follows the first tranche of tariffs on approximately $\$ 34$ billion of imports from China, which went into effect on July 6.[5], [6] Steel is not the main cause of the US trade deficit with China. In fact, in 2018, steel exports from China to the United States ranked only tenth below Brazil, South Korea, Canada, Mexico, Russia, Japan, Turkey, Germany and Taiwan. [7] Moreover, the price of steel from China is so cheap that it is able to defeat the steel of the United States. The Chinese government controls China's financial policy through the People's Bank of China which functions as the Central Bank of China. One of the policies of the Central Bank of China is to control the exchange rate of the Chinese Yuan or RMB against the US Dollar by selling Yuan or vice versa. The Central Bank of China until 2015 is believed to control the Yuan exchange rate so that it is weaker than the Dollar so that the price of its export products is cheaper on the global market.[8]

Based on this background the problems discussed in this study are:

1. Does the United States tariff policy conflict with the GATT/WTO?

2. What efforts should be made by the United States and China to resolve the tariff problem?

\section{Method}

\subsection{Approach Method}

This research was arranged based on the normative juridical method.

\subsection{Research Specification}

The specification of this research is descriptive analytics. This research is expected to give an idea whether the tariff policy by the United States of China against steel products is in conflict with the GATT/WTO and to describe what steps should be taken by the United States and China to resolve the tariff problem.

\subsection{Legal Material Collection Method}

This research was arranged based on the normative juridical method, therefore the data collection method used in this study was a literature study. The data used are secondary data as primary data, consisting of primary legal materials, secondary legal materials, and tertiary legal materials. Primary legal materials in this study include 1) General Agreement on Tariff and Trade 1994, 2) Agreement on Subsidies and Countervailing Measures; and 3) AntiDumping Agreement. Secondary legal material publications about the law that are not official documents which include textbooks, legal dictionaries, legal journals, and comments on court 
decisions. Tertiary legal materials used are legal materials that explain primary and secondary legal materials related to research, in the form of legal dictionaries, newspapers, and the internet.

\subsection{Legal Material Analysis Techniques}

The data obtained in the study were analyzed using qualitative data analysis methods, while for legal materials were analyzed using qualitative descriptive methods by describing relevant data. Then the reasoning is whether the data collected is contrary to existing legal material to draw conclusions about whether the facts found in this study are that the application of tariffs on Chinese steel and aluminum products by the United States is in line with GATT/WTO or violates GATT/WTO.

\section{Research Results and Discussion}

\subsection{Position Case}

Steel is a strategic industry for the United States because it is needed for a variety of constructions ranging from shipbuilding, tanks, bridge parts and energy infrastructure. The United States steel industry is threatened by the rise of the Chinese steel industry supported by government subsidies. This was stated by Steel Imports Surge Threatens U.S. National Security, a report published by American Manufacturing Alliance in spring 2016. The report explains that the strength of the Chinese steel industry can indirectly affect the security of the United States. [9]

The United States requires high-quality steel in large quantities to produce various military equipment, such as nuclear-powered submarines, tanks, and mine-resistant vehicles. Abram tanks for example require 22 tons of steel plates. [8] Types of light tactical vehicles in the class of Humvees Jeep require special steel and ceramic plates to protect their crew from the explosion of Improvised Explosives Devices. Meanwhile, the steel used to make Nimitz class aircraft carriers must be able to withstand the impact of 27 tons warplanes landing on the deck of the ship. In addition, the steel lining of the aircraft carrier must also be able to protect the crew from radiation produced by nuclear reactors that move the ship. Each aircraft carrier requires 50,000 tons of steel plates.[8]

The domestic steel industry in the United States has the ability to produce steel in accordance with specifications required by US military interests. [8] However, the steel industry does not get regular orders from the government. The main income of the United States steel industry depends on the consumption of steel outside the military. The entry of Chinese steel for consumption outside the military at lower prices threatens the sustainability of the United States steel industry because it could cause the American steel industry to close down. If the steel industries go out of business due to the entry of Chinese products, the United States will find it difficult to meet their military steel needs. This means it will threaten the security of his country as well. To prevent that from happening, President Donald Trump has set a tariff of $25 \%$ on Chinese steel products. The basis of these tariffs is the Trade Expansion Act of 1962, the contents of which can be implemented by the President of the United States when it is related to state security. This is quite different from the previous tariff implementations which do not need to use the Trade Expansion Act of 1962. 
China sells steel at a lower price because the Chinese steel industry is subsidized by the government and the Yuan exchange rate against the US Dollar is deliberately weakened. According to a report made by the Specialty Steel Industry of North America (SSINA) in April 2007, the Chinese government has subsidized the stainless steel industry on a large scale since 2005. The subsidies were not given to infant industries, and instead were given to large producers such as Shanghai Baosteel Group Corporation and Tangshan Iron and Steel. From January to August 2006, subsidies made Chinese steel production rise sharply, so Chinese steel imports continued to decline by 1.4 million metric tons or down thirty percent, and Chinese flat rolled stainless steel exports continued to increase to $60 \%$, which was 252,000 metric ton.[10] Subsidies from China do not only apply to the two steel companies above. A report from the 2015 American Steel Industry Coalition clearly illustrates subsidies by the Chinese government including the names of companies that receive subsidies, types of subsidies and subsidy granting procedures.

In 2014, Heibei Steel Group received assistance of 600.00,00 Yuan in the form of cash grants to encourage companies to, "innovate any constructive way to support industrial transformation and development." From the Ministry of Industry and Information Technology for the Remote Integration of Information Technology and Industrialization Funding, this funding is based on the 2011-2015 industrial transformation and improvement action plan and the instructions for transforming industrial investment to subsidize local firms to innovate in ecommerce.[10] Whereas in July 2012, the Ministry of Finance and the National Development and Reform Commission planned a program called financing guidelines for the economy aimed at increasing resource use and environmental protection, especially in recycling steel, metals, nonferrous metals, plastics, glass, and glass. The policy must be implemented by the local government, for example the Wuhan Development and Reform Commission and the Wuhan Finance Bureau provided funds of 1450,000 Yuan to Wuhan Wuxin New Construction material Co. Ltd in 2014 aimed at subsidizing energy saving and pollution prevention projects.[10]

Subsidies are in the form of financial policies within the form of Preferential Loans and Directed Credit. An example of a loan subsidy is that in March 2009, the Bank of Communications Shanghai Branch offered a loan of RMB 750 million to Baosteel Group to buy $56.15 \%$ of Ningbo Steel Co Ltd.'s shares. This is the first special loan case to support the government's steel industry consolidation policy. In 2009, Tianjin Steel Co. Ltd received an energy emission loan of RMB 43.9 million under the "green credit" program. The loan period is five years and is supported by the Industrial Bank, Beijing Bank, Shanghai Pudong Development Bank, and IFC. The most was in 2014 when the State Ethnic Affairs Commission gave Shougang Group a discount on the interest owed on loans worth RMB 12,791,400, and the Ministry of Trade and Ministry of Finance allocated RMB 13,183,809 in discounted loan interest for imported products, according to a report annual 2014. [10]

The Chinese government, both at the central and regional levels, provides various tax facilities both in the form of tax free policies and tax reductions that directly benefit the steel industry. The Chinese government's policy is to provide tax incentives for certain industries such as the steel industry, especially in industries that export their products to global markets. The Chinese government argues that this policy does not conflict with the WTO, and due to the pressure from international, the Chinese Government reduced the policy in 2014. However, in 2015, a number of parties reported that the Chinese Government still implemented the policy on a smaller scale.[10]

The Chinese government also provides electricity subsidies to the steel industry because the steel industry is one of the metal industries that requires huge electric power. The steel 
industry and other metal industries need furnaces that are capable of producing heat to the melting point of steel or other metals produced. The function of the melting furnace is very important because the steel ore must first be thawed to the new melting point after which it can be formed as needed.[10]

The allegations from America are based on research from several steel industry institutions or organizations and US academics which have been started since 2006. [11] The reports include: 1) Chinese Government Subsidies to Stainless Steel Industry by the Special Steel Industry of North America, which was made in 2007; 2) Shedding Lighton Energy Subsidies in China: An Analysis of China's Steel Industries From 2000 to 2007 by Usha C.V. Haley, published on January 8, 2008; 3) China's Specialty Steel Subsidies: Massive, Pervasive, and Illegal published by the Specialty Steel Industry of North America in October 2008; 4) China Steel Industries and It's Impact on The United States: Issues for Congress written by Rachel Tang of the Congressional Research Service and published on September 21, 2010; 5) Steel Imports Surge Threaten US National Security by the American Coalition of Manufacturing in 2016. At the peak of the existing reports are summarized in a report titled Report on Market Research Into The Peoples of the Republic of China Steel Industry by the Steel Industry Coalition on June 30, 2016. The report itself consists of 264 pages and is divided into three sections, the Steel Industry Coalition consists of the American Steel and Iron Institute, the Steel Manufactures Association, the Specialty Steel Industry of North America and the American Institute of Steel Construction.[8]

China then complained about the US Tariff policy to the WTO on April 5, 2018. The complaint stated that the US tariffs were not consistent with Articles 2.1, 2.2, 4.1, 4.2, 5.1, 7 , 11.1 concerning safeguards and Articles I: 1 , II: 1 (a) and (b), X: 3 (a), XIX: 1 (a) and XIX: 2 of the GATT 1994.[12] According to WTO rules, article 3.7 Dispute Settlement Understanding a complaint as made by China the settlement is done through a process of consultation between the disputing countries. If the consultation fails, the WTO will form a panel of dispute resolution on the request of China as the plaintiff. Based on article 17 of the DSU, a party to the dispute may begin an appeal review procedure against the panel report before Appellate Body through notice of appeal.[13] The United States refused the invitation for consultation from China because the invitation was about safeguard issues and not the tariffs.[14], [15]

The Chinese government eventually retaliated a $25 \%$ tariff on US steel products by applying a counter import tariff to the United States of $15-25 \%$, and items that would be subject to a tariff of 128 items. [16] The tariff includes tariff concessions that are suspended for 120 products and 8 other products subject to a 25 percent increase in tariffs.[17] Products that are suspended for concession rates include: dried and fresh fruits, almonds, tree nuts (pistachios), frozen pork, grapes, and stainless pipes. Then on July 3, 2018 China again implemented new tariffs targeting ranging from liquefied natural gas to several types of aircraft. The tariffs are estimated to have a total value of 60 billion US Dollars. This was done after the prospect of trade war talks with the United States became increasingly unclear. In August 2019 China imposed a new import duty of 75 billion US dollars or the equivalent of 1,050 trillion Rupiah to imported goods from the United States.[18]

The retaliation tariffs from China eventually received approval from the WTO.[19] The WTO Dispute Settlement Body decided that the tariff policy adopted by the United States violated GATT regulations, after the Chinese request for consultation on April 4, 2018 was unsuccessful. China asked the WTO to form a Panel on December 6, 2018 WTO, and the WTO formed a panel on January 28 2019, and the panel will start working on June 3, 2019. 


\subsection{United States Tariff Policy and GATT}

In 2016, China was not included in the top ten steel exporting countries to the United States, but Chinese steel exports affected the United States steel production. Overcapacity of Chinese steel production makes Chinese steel prices cheap, this causes the United States steel production to compete with Chinese steel. In 2015, China was the largest steel exporter in the world. In 2015, China's steel exports reached 110 million metric tons.[20] 2015 was a turning point for the United States, despite a decline in imports and import penetration, it should be noted that there was a drastic decline in production within one year. The decline in production was due to the close of some steel producers because they were unable to compete with more imported steel from China cheap. The United States Commerce Department noted a 35\% decline in the United States steel industry over three decades. The steel industry is not the only domestic industry in the United States affected by the entry of imported products, but this industry is one of the main domestic industries in the United States.[21]

China was only one of the top ten steel exporting countries to the United States in 2018. This further worsened the condition of the United States steel industry. Faced with this situation, the United States government made a tariff policy of $20 \%$ for steel products that entered the United States. Some steel exporting countries to the United States can negotiate so they are not affected by the tariff, but China failed to negotiate this is the cause of the United States trade war with China. The actual penetration of imported steel from China is not very significant and ranks only tenth out of the top ten imported steel sources in the US, with a percentage of two percent of the seventy-two percent of total steel imports to the United States. In terms of total import value, the value of imported steel from China in 2018 is less from one hundred million dollars.

The United States from the beginning has accused China of subsidizing and producing excessive steel, so that US steel products are unable to compete and the industry is threatened with closing. American Manufacturing Alliance stated in its report that steel products from China that made the United States steel industry shut down and gave a number of recommendations to prevent the closure of the US domestic steel industry, namely safeguards, Countervailing Measures, and Anti-Dumping Measures.[9]

The United States eventually applied tariffs to China in the form of countervailing measures and antidumping duties but did not apply safeguards. If the United States adopts safeguards, steel products from all over the world must be subject to tariffs without discrimination including those from US allies such as the European Union, Mexico and Canada. At first, the allies of the United States were indeed subjected to tariffs like China, but then the tariffs for Canada and Mexico were revoked after going through a negotiation process. Even in fact, Canada and Mexico are countries with a total steel greater than China in the graph of the top ten countries of imported steel product sources in United States of America. Negotiations with Canada and Mexico are conducted by the United States so that cheese and pork products are not subject to tariffs.

The United States anti-subsidized tariff is also questionable because in Article 6 of the SCM, to be able to apply a country's anti-subsidized tariff must be able to prove in advance that subsidies made by other countries cause losses to the domestic industry because not all subsidies are prohibited. If the United States accuses China of carrying out subsidies it should be consulted, and when it does not succeed, then the problem can be brought to the panel. In this case, the United States must prove. Based on data from the Steel Industry Coalition, there is indeed evidence of subsidies by the Chinese Government to the steel industry, whether it is 
done directly by the central government, regional governments, or state-owned banks. With subsidies in the form of direct delivery of funds which include direct assistance, capital injections, loans, taxes, facilities, equipment and ownership of private companies by the state, both directly and indirectly. However, in the end, the Committee on Subsidies will decide whether retaliation is permissible.

\subsection{Efforts to Be Made by the United States and China to Resolve the Tariff Issue}

The WTO as a world trade organization prohibits dishonest trade, but the WTO does not have the authority to impose sanctions on its member countries that commit unfair trade. However, it gives the right to member countries who are victims of dishonest trade to take retaliatory measures. If the country affected by the counter-action feels that the counter-action imposed on it is wrong, or the country feels that it is not conducting an unfair trade, the country that is the target of the counter-action can consult with the country that is taking the countermeasure. If the consultation resolves the existing problem, then the target country does not need to take the case to the WTO Dispute Settlement Body (DSB). However, if the consultation effort is unsuccessful the problem will proceed to the Dispute Settlement Body.

In this case, the United States has submitted a letter to the DSB chair to be circulated to members of a communication responding to a consultation request from China by requesting the Dispute Settlement Body on April 13, 2018. In order to communicate it, China asked the DSB chair on April 25 to respond to the United States consultation request on 13 April. On October 18, 2018, China requested the formation of a panel, at a meeting suspending panel formation. On January 7, 2019 China asked the Director General to prepare the panel, and the Director General arranged the panel on January 25, 2019. On September 4, 2019 the panel chairperson informed the DSB that the panel was expected to publish its final report to the parties no earlier than spring 2020, the chairman the panel also informed DSB that the latest report would also be available to the public when it was distributed to members in three WTO institutions.[22]

The steps above are the disputing countries. Should the United States accusing China of subsidizing its steel products may take temporary action on Chinese products., However, the allegations of subsidies must still be proven through an investigation by the WTO Committee on Subsidies, and the United States, as a country accused of damage the effect of subsidies should prove the causality between subsidies with serious losses or the threat of serious losses. If there are other factors that cause serious losses, then the subsidy cannot be linked. The United States must not only prove the existence of subsidies from the Chinese Government, but also must prove that the subsidies carried out by the Chinese Government violate the GATT/WTO and can be acted upon. GATT/WTO classifies subsidies as prohibited, not prohibited, actionable, and non-actionable subsidies.

The United States as a country that considers its steel industry threatened by Chinese export products should state explicitly that the action taken by the United States is actually a Safeguard action, and its implementation must be carried out in accordance with the provisions imposed by the GATT/WTO, namely with American conditions. The union has carried out an investigation in accordance with article 10 of the GATT 1994. In addition, the investigation must be made known to all interested parties, importers, exporters and other interested parties must be given the opportunity to submit evidence and views whose contents include whether the application of safeguards protect the public interest, investigation results and conclusions must be published in the form of a report by the investigator.[23] The investigation must objectively demonstrate the causality between increasing imports of the 
product concerned with heavy losses or the threat of heavy losses, if there are other factors that cause losses then it should not be associated with increased imports. [23]

\section{Conclusion}

Based on the analysis described in the previous chapter it can be concluded that:

1. In relation to the US tariff policy on steel products from China, the United States violates one of the principles of non-discrimination GATT/WTO. In this case the Most-favored-nation (MFN) contained in article 1.1 of GATT 1947 because it has created arbitrary tariff barriers. The United States does not impose tariffs on all steel exporting countries such as Mexico, Canada, Argentina, and Australia.

2. In connection with disputes for tariff implementation, the United States and China can resolve their disputes through consultation efforts. If the consultation is not successful, the two disputing countries can submit to the DSB, and the DSB will form a panel. If the panel does not accept the decision, the dissatisfied party can forward the case to the Apellate Body. If this effort still does not work, the United States and China can resolve it through their chosen arbitration institution. 


\section{References}

[1] M. Sood, Hukum Perdagangan Internasional. Jakarta: PT RajaGrafindo Persada, 2011.

[2] P. E. R. Simanjuntak, Anti Dumping dalam Penentuan Harga Normal dan Produk Sejenis dalam Menetapkan Kebijakan. Jakarta: Jala Permata Aksara, 2019.

[3] World Trade Organization (WTO), "Members and Observers." [Online]. Available: https://www.wto.org/english/thewto_e/whatis_e/tif_e/org6_e.htm. [Accessed: 17-Oct2019].

[4] GovTrack.us, "H.R. 4444 - 106th Congress: China Trade bill," 15 May 2000. [Online]. Available: https://www.govtrack.us/congress/bills/106/hr4444. [Accessed: 01-Jun-2019].

[5] United States Trade Representative (USTR), "USTR Finalizes Second Tranche of Tariffs on Chinese Products in Response to China's Unfair Trade Practices," 7 Aug 2018. [Online]. Available: https://ustr.gov/about-us/policy-offices/press-office/pressreleases/2018/august/ustr-finalizes-second-tranche. [Accessed: 24-Oct-2018].

[6] M. Faisal, “Trade War AS vs. China: 'What About Indonesia?' Report on Economic Justice Discussion of Indonesia for Global Justice," 12 April 2018. [Online]. Available: http://igj.or.id/wp-content/uploads/2018/10/IGJ_Economic-Justice-Seriesof-Discussion_Trade-War.pdf. [Accessed: 15-Jul-2019].

[7] Global Steel Monitor, "Steel Imports Reports: United States,” 2018.

[8] Steel Industry Coalition, "Report on Market Research into the Peoples Republic of China Steel Industry," 30 June 2016. [Online]. Available: https://www.steel.org/ /media/Files/AISI/Reports/Steel-Industry-Coaliton-Full-FinalReport-06302016.

[9] Alliance for American Manufacturing, "Steel Imports Surge Threatens U.S National Security," $2016 . \quad$ [Online]. Available: https://s.bsd.net/aamweb/main/page/file/a2f07fbe82f14e4b8c_xtm6bvc5c.pdf.

[10] Specialty Steel Industry of North America (SSINA), Chinese Government Subsidies to the Stainless Steel Industry. Washington, DC, 2017.

[11] G. T. Haley, U. C., and Haley, "Subsidies and the China price," Harv. Bus. Rev., vol. 86, no. 6, pp. 25-26, 2008.

[12] World Trade Organization (WTO), "China initiates WTO dispute complaint against US tariffs on steel, aluminium products," 9 Apr 2018. [Online]. Available: https://www.wto.org/english/news_e/news18_e/ds544rfc_09apr18_e.htm. [Accessed: 04-Aug-2019].

[13] J. W. Van den Bossche, P., Natakusumah, D., and Koesnaidi, Pengantar Hukum WTO (World Trade Organization). Jakarta: Yayasan Pustaka Obor Indonesia, 2010.

[14] D. C. Shea, "Permanent Mission of the United States of America to The World Trade Organization." [Online]. Available: https://ustr.gov/sites/default/files/files/Press/Releases/US.Reply.CHN.Cons.Req.SG.A pr3pdf.pdf. [Accessed: 19-Nov-2019]. 
[15] World Trade Organization (WTO), “United States: China's Response to U.S. Steel and Aluminum Tariffs Is Baseless." [Online]. Available: https://ustr.gov/aboutus/policy-offices/press-office/press-releases/2018/april/united-states-china's-responseus. [Accessed: 19-Nov-2019].

[16] S. R. D. Setiawan, "Balas Kebijakan Trump, China Kenakan Tarif Impor 128 Produk dari AS," 2 Apr 2018. [Online]. Available: https://ekonomi.kompas.com/read/2018/04/02/094006926/balas-kebijakan-trumpchina-kenakan-tarif-impor-128-produk-dari-as. [Accessed: 19-Nov-2019].

[17] A. Merelli, "The Complete List of 128 US Products Targetted by China's retaliatory Tariff," 2 Apr 2018. [Online]. Available: https://qz.com/1242652/china-tariffs-thecomplete-list-of-128-affected-good-class-of-goods/. [Accessed: 04-Aug-2019].

[18] Redaksi CNBC Indonesia, "Balas Trump, China Kenakan Tarif Baru ke Rp1.050 T Produk AS," $23 \quad$ Aug 2019. [Online]. Available: https://www.cnbcindonesia.com/news/20190823210029-4-94350/balas-trump-chinakenakan-tarif-baru-ke-rp-1050-t-produk-as. [Accessed: 19-Nov-2019].

[19] A. Swanson, "WTO Allows China to Impose Sanction. New York Times," 1 Nov 2019. [Online]. Available: https://www.nytimes.com/2019/11/01/business/wto-chinaus-trade.html. [Accessed: 09-Nov-2019].

[20] International Trade Administration Department of Commerce USA, "Steel Exports Report: China. Global Trade Steel Monitor (September 2016).” [Online]. Available: https://legacy.trade.gov/steel/countries/pdfs/2016/q2/exports-china.pdf.

[21] S. Horsley, "Trump Formaly Ordered Tariff On Steel. National Public Radio," 8 Mar 2018. [Online]. Available: https://www.npr.org/2018/03/08/591744195/trumpexpected-to-formally-order-tariffson-steelaluminum-imports. [Accessed: 04-Aug-2019].

[22] World Trade Organization (WTO), "DS544: United States - Certain Measures on Steel and Aluminium Products." [Online]. Available: https://www.wto.org/english/tratop_e/dispu_e/cases_e/ds544_e.htm. [Accessed: 27 Nov-2019].

[23] S. Dirdjosisworo, Kaidah-kaidah Hukum Perdagangan Internasional: Perdagangan multilateral versi organisasi perdagangan dunia WTO. Bandung: Penerbit CV. Utomo, 2004. 